\title{
Inovação para a sustentabilidade em produtos de base florestal sob a perspectiva do design
}

\author{
Aguinaldo dos Santos \\ Programa de Pós-graduação em Design / Universidade Federal do Paraná \\ Professor Doutor, asantos@ufpr.br
}

\section{RESUMO}

Inicialmente apresenta-se uma visão geral de projetos realizados pelo Núcleo de Design \& Sustentabilidade/UFPR com ênfase em recursos e resíduos de origem florestal (móveis feitos com nós de madeira certificada; componentes da habitação com compósitos de madeira manufaturados via compressão a frio; painéis cimento-madeira para habitação, retrofit de móveis, siding de compósito de madeira, produtos com nanocelulose). A seguir argumenta-se que a utilização de recursos naturais com uma ênfase eminentemente antropocêntrica, desconsiderando as necessidades de outras formas de vida, contribui para explicar vários fenômenos (ex: climáticos, epidemiológicos) que paradoxalmente afetam a própria qualidade de vida humana. Neste sentido, nesta apresentação será também apresentado uma perspectiva não antropocêntrica do uso dos recursos extraídos de florestas urbanas, exemplificando a fala através de produtos e serviços orientados a outras formas de vida. Dentre os exemplos está a aplicação dos resíduos de florestas urbanas na produção de colmeias para abelhas nativas (melíponas).

Palavras-chave: recursos naturais, resíduo florestal, biocentrismo, inovação, sustentabilidade.

\section{ABSTRACT}

Initially, an overview of projects carried out by the Design \& Sustainability Center / UFPR is presented with an emphasis on resources and residues of forest origin (furniture made with certified wood knots; housing components with wood composites manufactured by cold compression; panels cement-wood for housing, furniture retrofit, wood composite siding, nanocellulose products). Next it is argued that the use of natural resources with an eminently anthropocentric emphasis, disregarding the needs of other forms of life, contributes to explain various phenomena (eg. climatic, epidemiological) that paradoxically affect the very quality of human life. In this sense, this presentation will also present a nonanthropocentric perspective on the use of resources extracted from urban forests, exemplifying speech through products and services oriented to other forms of life. Among the examples is the application of residues from urban forests in the production of hives for native bees (melipona).

Keywords: natural resources, forest waste, biocentrism, innovation, sustainability. 